Published in final edited form as:

Langenbecks Arch Surg. 2009 January ; 394(1): 17-30. doi:10.1007/s00423-008-0339-x.

\title{
Food Fight!:
}

\section{Parenteral Nutrition, Enteral Stimulation and Gut-Derived Mucosal Immunity}

Joshua L. Hermsen, MD ${ }^{a}$, Yoshifumi Sano, MDa ${ }^{a}$, and Kenneth A. Kudsk, MDa,b

a Department of Surgery, University of Wisconsin School of Medicine and Public Health, Madison, Wisconsin, United States of America

b Veterans Administration Surgical Services, William S. Middleton Memorial Veterans Hospital, Madison, Wisconsin, United States of America

\begin{abstract}
Nutrition support is an integral component of modern patient care. Type and route of nutritional support impacts clinical infectious outcomes in critically injured patients. This article reviews the relationships between type and route of nutrition and gut-derived mucosal immunity in both the clinical and laboratory settings.
\end{abstract}

\section{Keywords}

parenteral nutrition; mucosal immunity; immunoglobulin A; polymeric immunoglobulin receptor; pneumonia

\section{Introduction}

Since the 1960's, use of parenteral nutrition (PN) solutions allowed metabolic support to patients with non-functional or severely injured gastrointestinal (GI) tracts. PN serves as a long term, life-saving necessity for many patients with a short or chronically dysfunctional gut, and a "nutritional bridge" during illness for others.

The history and practice of providing patients with nutrient substrates intravenously predates current methods of PN, total parenteral nutrition (TPN), or parenteral hyperalimentation. Publications from the 1950's described infusions of human serum albumin or protein hydrosylates of casein to provide substrate to patients unable to consume or absorb sufficient calories by mouth. ${ }^{1-3}$ An emulsified preparation of fat called Lipomul provided an additional intravenous energy source. ${ }^{4-6}$ However, technical advances in central venous catheterization techniques allowed for true intravenous alimentation with more complex substrates in concentrated solutions tolerated by patients. ${ }^{7,}{ }^{8}$ Contemporary parenteral feeding proved to be a breakthrough technique which allowed administration of adequate calories to meet energy expenditure and allow growth. ${ }^{9}$

Clinical use of PN increasingly spotlighted an interesting "man-made" and biologically artificial state of decreased enteral stimulation (DES), or gut rest, while preventing progressive malnutrition. Prospective clinical trials comparing type and route of nutrition demonstrated important differences between parenteral and enteral treatment groups with increased infection rates in critically ill patients fed parenterally. ${ }^{10-13}$ Questioning what mechanisms might

Corresponding author: Kenneth A. Kudsk, MD, 600 Highland Ave, H4/736 CSC. Madison, WI 53792-7375. Tel: 608-263-1396 Fax: 608-263-7562, email: kudsk@ surgery.wisc.edu. 
increase clinical vulnerability to these infectious complications, investigators investigated the effect of PN/DES on gut related immunity.

The gastrointestinal associated lymphoid tissue (GALT) is the largest (by total mass) human secondary immune organ and an integral component of the body-wide mucosal associated lymphoid tissue (MALT). ${ }^{14}$ MALT comprises all lymphoid cells and tissue protecting the internal body-world interfaces lined by an epithelial cell layer. Some GALT tissues, such as Peyer's patches (PP) and the appendix, are visible clinically, but individual cells within the gut epithelia and a layer of cells in the lamina propria (LP) account for a larger portion of GALT cell mass. For the purpose of this discussion, gut immunity and GALT function are synonymous. The status and function of gut immunity during PN/DES also carries implications for extra-intestinal mucosal immunity in clinically relevant sites such as the lung. This paper reviews the basic scientific and clinical knowledge regarding relationships between PN/DES, gut immunity, and extra-intestinal mucosal immunity within an anatomic framework.

These newly defined relationships are generally underappreciated by clinicians. Among healthcare providers, surgeons are in a unique and favorable position to observe, study and manipulate the relationships between gut function and immunity, nutrition support, and injury/ illness.

\section{Mucosal Immune Overview}

Mammalian immune systems must provide whole body protection against a plethora of antigens that can gain access to the host via differing portals. Direct contact between the animal and pathogen is the most basic route of inoculation. Intact skin provides a substantial and usually highly effective barrier to such invasion. However the skin represents a relatively small surface of the animal directly exposed to the outside environment. The mucosal surfaces of the respiratory, gastrointestinal, salivary, genitourinary, and mammary tracts collectively represent a huge area of potential exposure to the environment, with varying degrees of risk for pathogen exposure and invasion. Mucosal immunity at these sites provides a coordinated system of defense against this invasion. ${ }^{15,16}$

Development of the orally administered polio vaccine demonstrated practical evidence of gut immune function decades ago. The GI tract provided both a convenient route for delivery of the antigen and an instrument to initiate the desired immune response. Distinct recognition of secretory immunoglobulin A and specialized immune function to protect mucosal sites was first written about in the 1960's. ${ }^{17}$ Experimental evidence of the mucosal immune system as we know it currently advanced in the 1970's as several investigators showed that exposure to antigen at one mucosal surface generated immunity to the same pathogen at other, non-exposed, mucosal sites. ${ }^{18,19}$ Further investigations led to the development of the 'common mucosal immune hypothesis' that generally describes the anatomic, immunologic and mechanistic framework responsible for providing immunity at mucosal sites throughout the body. ${ }^{19}$

Mechanistically, the mucosal immune system is composed of inductive and effector sites. ${ }^{20}$ While anatomically there is some overlap between such them, they will be considered as distinct entities for simplicity (Figure 1).

Peyer's patches serve as the inductive site for antigen absorption and immunologic processing for sensitization of mucosal immunity. ${ }^{21,22}$ Peyer's patches are anatomically distinct (more so in rodents than humans) collections of immune cells found on the anti-mesenteric border of the small intestine throughout its length. Peyer's patches display follicular architecture, similar to lymph nodes, with distinct areas rich in T and B lymphocytes. ${ }^{23}$ The luminal surface overlying Peyer's patches contain specialized epithelia termed M cells that function to sample, capture and shuttle antigens to the underlying Peyer's patch components. ${ }^{24}$ Simultaneously, 
naïve lymphocytes migrate out of the circulation into PP for activation if exposed to their cognate antigen. ${ }^{25}$

From the PP, activated lymphocytes travel via efferent lymph channels to the mesenteric lymph nodes and through the thoracic duct into the systemic circulation. ${ }^{26}$ Homing of such activated lymphocytes back to mucosal immune effector sites occurs by a specific process likely regulated in combination by factors including cellular adhesion molecules, cytokines and chemokines.

Once returned to an effector site (generally regarded as the lamina propria underlying a mucosal surface and the lymphatic cells therein), T and B lymphocytes work in conjunction for IgA production by terminally differentiated B cells termed plasma cells. ${ }^{27} \mathrm{~T}$ cells, predominated by Th- 2 type cells, enrich the milieu with IgA production stimulating Th- 2 cytokines such as interleukin-4 (IL-4), and IL-10. The end product of this process is dimeric IgA consisting of 2 IgA monomers structurally linked at the constant region by a small peptide called J-chain. ${ }^{28}$

Transepithelial transport from the lamina propria to the mucosal surface occurs actively via a specific membrane bound protein transporter called polymeric immunoglobulin receptor (pIgR) ${ }^{29} \mathrm{pIgR}$ is a 7 domain membrane spanning protein present on the basolateral surface of epithelial cells capable of binding, transporting and releasing immunoglobulin onto the apical cell surface. ${ }^{30}$ Five of the seven pIgR domains (termed secretory component, SC) remain attached to the antibody yielding an IgA + J-chain $+\mathrm{SC}$ complex referred to as secretory $\operatorname{Ig} \mathrm{A}$ (SIgA, Figure 2) ${ }^{30}$ SIgA provides the principle antigen-specific immunologic defense against potential pathogens at all mucosal surfaces. ${ }^{31-33}$

This model provides the classic description of the pathway to mucosal immune response activation but variations on the theme exist. For example, "extra-follicular" pathways appear to exist where lamina propria B cells can be induced by local factors to undergo class switch recombination to IgA+. ${ }^{34} \mathrm{~T}$-cell independent pathways also yield IgA plasmablasts able to produce antigen-specific IgA. In the mouse, naïve B cell populations are generated in both the pleuro-peritoneal (B1) and bone marrow (B2) spaces: the former is able to mature independently of $\mathrm{T}$ cell help and ultimately contribute $\sim 50 \%$ of intestinal IgA production. ${ }^{35}$,

${ }^{36}$ In humans the bone marrow appears to be the sole source of naïve B cells.

This discussion of the interplay between type/route of nutrition and gut immunity uses the classically described mucosal immune pathway.

\section{Peyer's Patches (PP)}

The observation that cholera toxin inoculation of isolated intestinal loops lacking PP generated ineffective mucosal immune responses confirmed that PP play a role in driving mucosal immune induction ${ }^{22}$. The effect of PN/DES on Peyer's patches as the major inductive sites for generation of mucosal immune responses is a natural starting point for investigation. PN solution administered intravenously or intragastrically leads to significant PP morphologic changes with reductions in PP total lymphocyte populations in different species. ${ }^{37-39}$ This decrease in total lymphocyte number represents decreases in both B and T cells. However the ratio of B to T cells in the PP remains constant at approximately two to one. Similarly, within the PP T cell population, the ratio of CD4 to CD8 cells is not affected by PN feeding and remains constant at approximately $4: 1 .^{38}$ Peyer's patches receive no afferent lymphatic flow but are supplied by small blood vessels known as high endothelial venules (HEV). ${ }^{40} \mathrm{HEVs}$ express adhesion molecules which attract and direct a specific complement of cells into the PP. One adhesion molecule, mucosal addressin cellular adhesion molecule-1 (MAdCAM-1), interacts specifically with naïve lymphocytes displaying L-selectin and $\alpha 4 \beta 7$ on their cell 
surface. ${ }^{41,42} \alpha 4 \beta 7$ is a specific cell surface marker expressed on cells destined for a mucosal immune fate.

Animals fed parenterally express significantly less MAdCAM- 1 in PP. ${ }^{43}$ In fact, levels of MAdCAM-1 messenger RNA begin to decrease within 8 hours of initiating PN/DES and show a statistically significant decline by 24 hours and remain low if PN/DES continues. ${ }^{44}$

MAdCAM-1 protein levels drop significantly within 12 hours of fasting and continue at low levels compared to chow after 5 days of PN/DES. ${ }^{43}$ This seems to be an effect specific to the Peyer's patches as levels of MAdCAM-1 in the small intestine and mesenteric lymph nodes of PN/DES animals remain unchanged from their chow counterparts. ${ }^{45}$ If PN/DES animals receive a chow diet, MAdCAM-1 levels rapidly recover to near normal (Figure 3) ${ }^{45}$ Blockade of MAdCAM-1 with specific blocking antibodies confirmed its functional role in maintaining PP cell populations. Chow animals administered a monoclonal antibody, MECA-367, which blocks MAdCAM-1, reproduced the PP lymphocyte depletion seen with PN/DES. ${ }^{45}$

A series of experiments demonstrated that MAdCAM-1 changes occur due to impaired stimulation of the pathway responsible for its production. PN/DES decreases the level of lymphotoxin beta receptor (LT $\beta R$ ) ${ }^{46}$ a molecule critical to mucosal immune system development. ${ }^{47,}{ }^{48}$ LT $\beta R$ provides the stimulus for MAdCAM-1 and IL-4 production via activation of the nuclear factor kappa B (NFKB) pathway. ${ }^{49}$ Administration of a LT $\beta R$ agonist antibody to PN/DES animals increased PP lymphocyte counts to chow levels. ${ }^{46}$ Conversely, blockade of LT $\beta$ R in chow fed animals using a fusion protein construct led to decreases in the levels of MAdCAM-1 mRNA transcripts and number of lymphocytes in the PP. ${ }^{50}$ Despite the variety and severity of changes in the PP seen with PN/DES, the levels of MAdCAM-1 and lymphocyte populations of DES/PN animals can be restored to normal levels in less than 4 days with reinstitution of chow feeding. ${ }^{45,51}$

Studies of PN/DES in rabbits showed additional morphologic and functional PP changes. ${ }^{37}$ M-cell structure appears unchanged by PN/DES but M-cell mediated antigen uptake drops with PN feeding. ${ }^{37}$ However it remains unknown whether this change reflects a decrease in antigen present within the lumen or a true disability of the $\mathrm{M}$ cell to take up antigen from the lumen.

\section{Mesenteric Lymph Nodes}

The mesenteric lymph nodes (MLN) provide the first immunologic site at which one can assess the status of lymphocytes after they traversed the PP and possibly became activated by antigen exposure. Normal chow fed mice increase the percentage of B cells possessing cytoplasmic IgA from $2 \%$ in PP to $50 \%$ in MLN. ${ }^{52}$ However, the percentage of total MLN lymphocytes derived from PP sources probably remains small as the numbers of total lymphocytes in MLN of PN fed animals do not change. ${ }^{38}$ Since PN feeding does not overtly affect the size of MLN cell populations, little specific immunologic data exists on the effects of PN/DES at this site.

Many investigators focused experimentally on MLNs as they relate to bacterial translocation after altering the type and route of nutrition. In such studies, MLN are cultured for bacteria to judge whether bacteria translocated across the intestinal epithelial barrier to the nodes. A significant amount of work clearly demonstrates that animals (predominately rat models) undergoing decreasing enteral stimulation (as with $\mathrm{PN}$ and no oral intake) have significantly increased bacterial presence in mesenteric lymph nodes ${ }^{53-55}$ The burden of bacterial translocation was magnified with the addition of a stress/injury to an animal treated with decreased enteral stimulation. ${ }^{56-58}$

Several clinical trials have examined bacterial translocation in humans. Two published trials microbiologically examined the relationship between bacterial translocation to MLNs and infectious outcomes. Type and route of nutrition were not variables in either study. One study 
found that age $>70$ years, non-elective operation and proximal GI operation were significant risk factors for bacterial translocation and that post-operative infection was more common in these patients. ${ }^{59}$ However, the bacteria cultured from the GI tract, MLN and infection sites correlated with each other less than half of the time. Another study produced similar findings with an overall translocation rate of $15 \%$. Concomitant translocation and bacteremia occurred in $2 \%$ of patients and concomitant translocation and bacteremia with the same organism occurred in less than one percent of patients. ${ }^{60} \mathrm{~A}$ British human study examined bacterial translocation incidence related to the variable of type and route of nutrition. In this nonrandomized study of patients undergoing elective laparotomy, the authors found no difference in mucosal health (as judged microscopically by atrophy) or bacterial growth from MLN when comparing 28 patients receiving TPN exclusively for $\geq 10$ days pre-operatively and 175 patients who ate normally until the evening prior to operation. ${ }^{61}$ It remains unclear if bacterial translocation and increased permeability play any significant role in clinical outcomes such as infection, sepsis, or multiple organ failure and death. Many consider bacterial translocation as an irrelevant epiphenomenon with little clinical relevance.

Since most work to date involving PN/DES and MLN has focused on bacterial translocation, little information exists about basic molecular and immunologic events in the MLN. This may largely be a function of tissue availability because processing MLNs to assess translocation destroys the sample for additional molecular, protein or cellular analysis. Perhaps this void is best highlighted by the rather conspicuous absence of information regarding MLN in a recent review article in the inaugural issue of Mucosal Immunology titled, "The immune geography of IgA induction and function" co-authored by Per Brandtzaeg, one of the foremost modern mucosal immunologists. ${ }^{62}$

\section{Thoracic Duct and Systemic Circulation}

While sometimes regarded by mucosal immunologists as simple conduits for lymphocytes, important events occur within the thoracic duct and systemic vasculature. Evidence points to ongoing maturation of B cells in transit as evidenced by an increase in the percentage of IgA + B cells from 50\% in the MLN to 75\% within thoracic duct lymph. ${ }^{52}$ Effects of PN/DES on the systemic circulation and endothelium are profound. PN/DES alters the expression of multiple endothelial cellular adhesion molecules within multiple organs. In animal experiments, PN feeding significantly increases the small intestine expression of intercellular adhesion molecule-1 (ICAM-1), a primary neutrophil chemoattractant. ${ }^{63}$ Additional tissue specific neutrophil adhesion molecules, such as P- and E-selectin (in the intestine and lung respectively) simultaneously increase with PN (Table 1). ${ }^{64}$ Increases in gut myeloperoxidase (MPO) activity accompanied the increased expression of these adhesion molecules allowing interaction between the endothelium and the cells (Table 1). ${ }^{63}$ This interaction "primes" the neutrophils to generate an augmented inflammatory response to subsequent insults. The "primed" cells migrate from the gut vasculature to other tissues such as the lung and liver. If no subsequent insult or injury occurs, the cells simply disappear with time but if a subsequent insult occurs, the "primed" cells respond with intense inflammatory responses capable of injuring the tissue. Within the lung, PN/DES pretreatment generated a significant increase in pulmonary leukocyte expression of the $\beta 2$ integrin, CD18 activation marker after a mild insult of gut ischemia (15 min of SMA occlusion) followed by 2 hours of reperfusion. ${ }^{65}$ This cellular activation occurred only in parenterally fed animals resulting in increased lung (and liver) permeability and a higher mortality than enterally fed mice. ${ }^{66}$

The presence or absence of physical and biochemical enteral stimulation appears to be the key variable for gut and associated extra-intestinal mucosal immune function. This "all or nothing" phenomenon correlates with work from Teitelbaum et al. that showed a similar response pattern of gut mucosa and gut immune parameters to enteral stimulation. Mice fed $75 \%$ of caloric 
needs via IV-TPN and 25\% of calories via the gut displayed gut and gut immune phenotypes similar to animals fed $100 \%$ chow in a model using dual gastric and intravenous cannulation. ${ }^{67}$ Significant changes in gut and GALT phenotypes were noted only when $100 \%$ of calories were provided with IV-TPN with no enteral stimulation.

PN/DES also appears to modulate systemic inflammation through alteration in systemic cytokine signaling. Much of this evidence actually comes from human data gathered in both clinical and experimental settings. Japanese investigators examined patients with colorectal cancer and compared cytokine responses to identical surgical procedures performed in patients eating normally and those receiving $>7$ days pre-operative TPN. They found that the TPN significantly exaggerated post-operative systemic IL-6 and IL-8 responses compared to patients fed enterally before the operation. ${ }^{68}$ A separate study randomized patients undergoing 3 -field esophagectomy to PN/DES or enteral feeding 7 days pre- and 14 days post-operatively and found significant post-operative elevations in IL-6, IL-10 and endotoxin levels in the PN/ DES group ${ }^{69}$ Unfortunately neither study included enough patients to meaningfully study differences in postoperative clinical outcomes to correlate such differences with the type and route of nutrition support. Fong et al. randomized healthy volunteers within a clinical research center setting to 7 days of total parenteral nutrition or a defined, energy matched enteral diet. Subjects received intravenous endotoxin following seven days of feeding. Parenterally fed subjects experienced significantly greater increases in temperature, glucagon, epinephrine, $\mathrm{C}$ reactive protein and tumor-necrosis factor in response to the endotoxin challenge. ${ }^{70}$ Thus, the majority of evidence suggests that while PN feeding itself induces no inflammatory state, it may predispose subjects to an exaggerated response to normally inflammatory stimuli such as surgery or infection.

\section{Lamina Propria}

The lamina propria (LP) and epithelial cell layer comprising all mucosal surfaces constitute the "effector site(s)" of the mucosal immune system. ${ }^{71}$ The LP serves as the final destination for sensitized lymphocytes. Type and route of nutrition (especially PN/DES) induces several important changes in lamina propria lymphocyte populations. Firstly, the overall number of LP T and B lymphocytes significantly decreases following PN/DES. ${ }^{38}$ A dramatic change occurs in the ratio between $\mathrm{CD}^{+}$and $\mathrm{CD}^{+}$subsets within the LP T cell population. The normal $\mathrm{CD} 4^{+} / \mathrm{CD}^{+}$ratio (seen with chow feeding) is approximately $2: 1$. This ratio decreases significantly to 1:1 with PN/DES treatment due to a drop in $\mathrm{CD} 4^{+}$cells while the $\mathrm{CD} 8^{+}$cell subset remains stable. ${ }^{38}$ As in the PP, LP lymphocyte populations rebound to normal levels within just a few days of chow re-feeding. ${ }^{51}$ Thus, this system is extremely dynamic and exquisitely responsive to type and route of nutrition.

$\mathrm{LP} \mathrm{CD}^{+} \mathrm{T}$ cells normally produce the IgA -promoting T-helper-type 2 cytokines IL-4, IL-5, IL-6 and IL-10 which stimulate IgA production by the surrounding plasma cells within the lamina propria. ${ }^{27,} 72$ PN/DES reduces intestinal levels of IL-4 and IL-10 without affecting levels of interferon gamma, a Th-1 IgA inhibiting cytokine (Table 1). ${ }^{73}$, 74 The levels of these Th-2 cytokines correlated positively with levels of IgA recovered from the intestinal lumen indicating that PN with decreasing enteral stimulation does not overtly suppress or directly inhibit IgA production but rather leads to a decrease in stimulus prodding plasma cells to produce $\operatorname{IgA} .{ }^{73}$

The PN/DES induced cytokine changes appear related to the inflammatory changes described in the previous section. Both IL-4 and IL10 inhibit the expression of intercellular adhesion molecule-1 (ICAM-1), the adhesion molecule implicated in neutrophil accumulation and "priming" in the gut. ${ }^{63}$ As gut IL-4 and IL-10 levels decrease, levels of gut ICAM-1 rise in association with concomitant increases in gut MPO activity, $\mathrm{P}$ - and E- selectin expression, and 
leukocyte response to gut ischemia/reperfusion injury as the activated cells in the lung respond to this injury with an augmented inflammatory response.

Technically, the LP is a difficult "compartment" to study for in vivo IgA production. Cell populations isolated from fresh samples comes at the expense of the remaining tissue so that it is impossible to isolate both the lamina propria GALT stromal and cell constructs from the overlying epithelium. These limitations pose challenges in quantifying the amount of IgA present in the LP and available for transport across the epithelium. Immunohistochemical techniques are limited in providing "hard" quantitative outputs and are limited by their inherent "snapshot" nature. However, a truly quantitative measure of IgA "production" capability within the LP is required to understand the physical location and source of mucosal immune breakdown induced by differing types and routes of nutrition.

\section{Mucosal Epithelium and SIgA}

In the mucosal immune system morphology, the single celled epithelial layer represents the final component involved in placement of IgA onto the mucosal surfaces. While a structural barrier, the epithelia serves as the transport conduit for IgA via action of the specialized transport protein (produced by epithelial cells) called polymeric immunoglobulin receptor (pIgR). pIgR represents the exclusive transport pathway for IgA to move from the lamina propria, through the epithelia, and onto the mucosal surface.

Epithelial cells produce pIgR and the pIgR gene sequence is well conserved among primates, rodents, other mammals and birds. ${ }^{75}$ While sequence differences exist between such groups, the basic exon-intron structure remains unchanged. Single nucleotide polymorphic mutations in the $\mathrm{pIgR}$ gene are implicated in the pathogenesis of both IgA nephropathy and Epstein-Barr virus associated nasopharyngeal cancer. ${ }^{76,77}$ Immunologically, pIgR only transports polymeric immunoglobulins (poly-IgA or IgM in humans, poly-IgA only in mice) joined by the J-chain linker peptide. ${ }^{78}$ This peptide connects Ig monomers to form dimers or other polyIg configurations. Therefore individuals with normal pIgR but mutated or absent $\mathrm{J}$-chain are SIgA deficient at the mucosa. ${ }^{79,80}$ The exact details and site(s) determining the 3 dimensional interactions of $\mathrm{pIgR}$ and J-chain remain unknown.

Although necessary and efficacious for transepithelial transport of IgA, pIgR may provide other immune functions. Intracellular vesicles containing pIgR-IgA complexes may contain IgA that has already bound antigen. In this way, pIgR, and the natural SIgA transport process functions to 'excrete' antigens present within tissues. ${ }^{81}$ Additionally, a basal level of pIgR transcytosis occurs without IgA binding and exocytosis and cleavage of this 'empty' pIgR yields 'free' intra-luminal secretory component (SC). ${ }^{75}$ Free SC has direct antimicrobial properties against pathogens such as E. coli, ${ }^{82} \mathrm{H}$. pylori ${ }^{83}$ and $C$. difficile toxins ${ }^{84}$ due to $\mathrm{N}$-glycan chains similar to those found on lactoferrin. ${ }^{85}$ Furthermore, human SC contains a binding site specific for several Streptococcus pneumoniae surface antigens. ${ }^{86}$

We recently showed that type and route of nutrition affect pIgR expression in an organ specific manner (in press; Journal of Surgical Research). Within the small intestine, PN feeding significantly decreases pIgR levels (Figure 4 ) ${ }^{87}$ In the respiratory tract, however, PN feeding results in higher levels of $\mathrm{pIgR}$ protein in the lung with slight but insignificant increases in nasal passage tissue. The reasons for these differences remain unclear. The dichotomous response of pIgR to PN/DES between intestinal and extra-intestinal mucosal sites begs the question whether specific nutrients or physical factors regulate pIgR expression. Type and route of nutrition may affect intracellular trafficking processes that serve to route new $\mathrm{pIgR}$ to either the basolateral or apical surfaces. Epithelial cell calcium physiology may be involved as calmodulin binds to the basolateral targeting signal in rabbit pIgR. ${ }^{88}$ Alterations in the rate 
of transepithelial travel due to changes in phosphorylation of several key Serine residues remains another possibility. ${ }^{89}$

The "final destination" for SIgA is the mucosal luminal surfaces. Presumably, PN/DES affects mucosal immunity and levels of luminal SIgA through the cumulative effects occurring between Peyer's patches and the epithelial cell membrane as described thus far. Parenteral feeding with decreased enteral stimulation causes a reduction of SIgA at the mucosal interfaces of the small intestine, nasal passages and lungs. ${ }^{38,39,90}$ Over the course of the experimental 5 day PN feeding protocol, SIgA drops significantly within three days with continued decline throughout the study period (Figure 5) ${ }^{39}$ Curiously, the pattern of change in SIgA levels parallels the decline in PP lymphocyte populations, which in turn reflects decreasing levels of PP MAdCAM-1. (Figures 3 and 5) In this regard it appears that the integrity of the mucosal immune system, with adequate levels of SIgA, depends upon continuous expression of recruiter molecules and input of cells at inductive sites. The system appears very dynamic and responsive to dietary changes. This inherent fluidity is evident in the response to re-feeding parenterally fed mice with a normal chow diet. Re-feeding restores PP and LP lymphocyte populations to normal levels within 48 hours. ${ }^{51}$

\section{Is Mucosal Immune Function Influenced by Type and Route of Nutrition?}

Clearly, lack of enteral stimulation exerts global down-regulatory effects on mucosal immune parameters at both inductive and effector sites. However, to be clinically relevant, these changes must affect mucosal immune function and not just morphology. Models of both bacterial pneumonia and viral respiratory infection demonstrate that type and route of nutrition does negatively impact mucosal immune function and ability to deal with infectious challenge. Viral immunization of parenterally fed mice leads to production of significantly fewer antiviral antibody-forming cells in nasal passages consistent with impaired ability to generate effective anti-influenza immunity. ${ }^{90}$ Similarly, animals successfully immunized against influenza virus, and then fed parenterally, lose the ability to eliminate the virus from their nasal passages when re-challenged with a second dose. ${ }^{91}$ Immunity remains intact in enterally fed mice. Memory is not lost in PN-fed animals since chow refeeding for 3 days reestablishes effective immunity in the PN-fed animals. ${ }^{51}$ In models of lethal bacterial pneumonia, immunization with the bacterial antigens renders mice resistant to an intra-tracheal dose of Pseudomonas $(P s)$ that would be lethal to naïve mice as long as they are fed enterally. Previously immunized mice fed parenterally sustain a mortality rate similar to naïve, unimmunized mice. ${ }^{92}$

These observations appear consistent with data from clinical trials showing an increase in pneumonia in injured patients fed parenterally. ${ }^{10-13}$ We speculate that the mucosal immune 'tipping point' in this equation is the lowered level of IgA found in parenterally fed animals that is inadequate to fend off pathogen invasion and infection.

\section{Injury and Mucosal Immunity}

Clinical trials of severely injured trauma patients represent much of the clinical evidence supporting the observations that PN/DES increases infectious outcomes. Experimentally, secondary changes in mucosal immune status due to PN/DES provide a cogent explanation for these observations. Recently we observed that traumatic injury itself induces a mucosal immune response within the respiratory tract of both humans and mice. ${ }^{93}$ Severe trauma stimulates acute (within $24 \mathrm{hrs}$ ), statistically significant increases in human airway epithelial lining fluid and concentration of SIgA in the epithelial lining fluid. Mice respond in a similar fashion with acute increases in total airway IgA (Figure 6). In the human study, because the antibody used is specific for the SC, this increase reflects SIgA transported into the lumen rather than increases in lung permeability with leakage of serum IgA due to inflamed or 
damaged endo- or epithelium. These novel findings appear to represent an innate, preprogrammed protective response during a time of stress and vulnerability evident in both humans and other species linking systemic inflammation together with mucosal immune integrity in the respiratory tract. In vitro studies show that up-regulation of $\mathrm{pIgR}$ expression occurs following exposure to both tumor necrosis factor alpha (TNF-a) and interleukin-1-beta $(\mathrm{IL}-1 \beta) .{ }^{75},{ }^{94-96}$ Both cytokines are pro-inflammatory cytokines typically elevated during stress and following trauma. This hypothetical relationship between these inflammatory cytokines and pIgR levels was tested in the mouse model by pre-injury administration of antibodies antagonistic to TNF- $\alpha$ and IL-1 $\beta$. Blockade of TNF- $\alpha$ eliminated the increase in airway IgA in response to injury while IL- $1 \beta$ blockade produced a similar, but less pronounced inhibition of the IgA increase. (in press; Surgical Infections) Consistent with the hypothesis that PN/DES affected mucosal immune integrity, experiments showed that PN/DES treatment of mice for 5 days prior to injury lost the ability to respond to the injury stimulus with an increase in airway IgA (Figure 7). (in press; Surgical Infections) It appears that the trigger (the inflammatory stimulus) remains present and is possibly exaggerated, but the global mucosal immune impairment caused by the pre-injury PN/DES treatment eliminates normal respiratory protective responses to injury. The gas pedal can be pushed but there is no gas in the tank.

Interestingly, direct sympathetic stimulation also seems to play a role in producing $\operatorname{IgA}$ at mucosal surfaces furthering the notion that the mucosal immune system is connected to and can be driven by the systemic response to injury. Schmidt et al. showed that exogenous administration of catecholamines to ex vivo constructs of polarized pig intestinal tissue caused significantly more IgA to be secreted into the apical supernatant. ${ }^{97}$ Whether this effect was direct, or mediated by some other secondary signal (like a cytokine) is unknown.

\section{Mucosal Immune Adjuncts to Support GALT and MALT}

Few would argue against the statement that "enteral nutrition is superior to parenteral". The surgical dictum mandating "if the gut works, use it" will continue to be heeded by surgeons if for no other reason than to eliminate the inherent acute and long term risks associated with central venous catheterization. However a population of patients always exists with a nonfunctional or insufficient gut for absorption of nutrients that require PN as a necessary, lifesaving, and life-sustaining therapy. Ideally, one could mitigate the deleterious effects of PN/DES on mucosal immunity in these patients by supplementing PN. Two specific agents, glutamine and neuropeptides, have been investigated thus far for this purpose.

Glutamine, a conditionally essential amino acid and a major fuel for rapid turnover cellular systems such as the GI epithelium, has been studied clinically by both enteral and parenteral routes. However, its instability in solution (particularly with heat sterilization) limits its commercial availability for routine use. Obviously, clinical trials primarily measure clinical outcomes which may or may not be related to glutamine induced changes in mucosal immunity but laboratory studies allows investigations of how glutamine supplementation might influence mucosal immunity.

In the animal model, $2 \%$ glutamine supplementation of TPN results in normalization of small intestinal luminal IgA levels and lymphocyte counts in the PP (T and B cells), LP (B cells only) and IE ( $\mathrm{T}$ and $\mathrm{B}$ cells) spaces. ${ }^{100}$ More importantly, glutamine generates a functional improvement in respiratory antiviral immunity (decreased viral shedding following viral rechallenge) compared to PN alone. ${ }^{98}$ Glutamine supplementation also increases survival (compared to PN alone) in a lethal mouse pseudomonas pneumonia model. ${ }^{99}$ Two general forms of glutamine are available for clinical use: free glutamine or glutamine as a part of a synthetic dipeptide (L-alanyl-L-glutamine or glycyl-L-glutamine). The dipeptide dissolves 
more easily in solution and therefore is preferred in clinical use. Free glutamine or dipeptide glutamine produce similar beneficial effects in the animal model.

The neuropeptide bombesin, is a tetradecapeptide neurotransmitter isolated from the skin of the frog, Bombino bombino. ${ }^{100}$ Because of an identical terminal 7 amino acid structure at the functional position, bombesin's function is analogous to gastrin-releasing peptide in humans. ${ }^{101}$ Bombesin is not approved for human clinical use although it has been studied in several clinical trials and appears safe in humans. ${ }^{102-104}$

Given the extensive innervation of the gut as well as the specific neuro-immune interaction in PP suggested by structural studies, ${ }^{105}$ gut derived neuropeptides such as bombesin were studied for their affects on mucosal immune status during times of decreased enteral stimulation. Similar to glutamine, bombesin supplementation of PN exerted positive effects on GALT cell mass in the PP, LP and IE spaces. ${ }^{106}$ Bombesin maintained mucosal (intestinal and respiratory) IgA levels, ${ }^{106,107}$ and preserved intestinal IL-4 at chow levels. ${ }^{107}$ Similar to glutamine, the ability of bombesin to maintain these mucosal immune parameters translated into significant functional improvements on the whole organism level compared to mice given PN/DES. Bombesin supplemented PN mice maintained normal antibacterial respiratory defenses compared to PN alone. ${ }^{106}$

Exactly how glutamine and bombesin exert these beneficial effects remains unclear. They do not work through MAdCAM- ${ }^{108}$ and may directly affect immune cells themselves, stimulate other pathways of cell migration or prolong cell survival. Current studies examine their effects on other important mucosal immune parameters such as LT $\beta$ R, various Th-2 type cytokines and $\mathrm{pIgR}$.

\section{Is there evidence of nutrition- altered mucosal immunity in humans?}

Our knowledge of the link between type/route of nutrition and human mucosal immune parameters trails the experimental evidence in animals but some substantiating data exists. Several human studies showed that lowered mucosal IgA levels were associated with reduced resistance to infection, specifically pneumonia. ${ }^{32,}{ }^{109}$ Neonatal studies convincingly demonstrate that populating the GI tract with immunoglobulin-producing cells and intraepithelial GALT cells depend upon some enteral nutrient stimulation. ${ }^{110-112}$ The degree to which the reciprocal of this process exists in adult humans poses a practical question that remains inadequately investigated but a potentially fruitful area for research. Clinically, investigators confirmed decreases in LP GALT cells in pre-operative PN fed colon cancer patients compared to similar patients allowed oral intake prior to surgery. ${ }^{113}$ Wijesinha et al. compared biopsies from proximal and distal limbs of loop ostomies and found more GALT cells present in the proximal limbs exposed to the nutrient stream, than in the distal limbs from which the nutrient stream was diverted. ${ }^{114}$ Conversely, Buchman et al. reported no differences in GALT cell populations taken by jejunal "bite biopsy" in healthy volunteers supported exclusively with PN for 14 days in a clinical research center and concluded that type and route of nutrition did not affect intestinal immune function in man. ${ }^{115}$ However the ability of several small biopsies to define changes in total GALT mass and function in otherwise healthy, nonhospitalized patients remains unproven. Unfortunately comprehensive examination of the diverse mucosal immune parameters measured experimentally is generally not feasible in acutely ill hospitalized patients.

\section{Summary}

The objective of this review was to inform the reader of a relatively unknown, but rapidly expanding area of investigation underlying common questions related to nutrition support and patient outcomes. Certainly nutrition support matters, but remains difficult to study and 
exceedingly difficult to quantify. The nutrition support issues of how, when, how much, what kind, in what patient and for how long continue to be studied and debated with relatively limited data available given that nutrition support is a therapy prescribed to nearly every patient.

Parenteral nutrition is, and will continue to be, a necessary and life-saving therapy for patients with inadequate gut length and/or function. However, the recognition that disuse of the alimentary tract in such patients may have real immunosuppressive consequences is an emerging idea and deserves therapeutic consideration. Continued study in animal models should aim to identify and test quality therapeutic targets in order to provide a fund of knowledge from which to launch truly translational clinical research.

\title{
Acknowledgments
}

\author{
Supported by: \\ -NIH Grant R01 GM53439
}

-This material is based upon work supported in part by the Office of Research and Development, Biomedical Laboratory R\&D Service, Department of Veterans Affairs.

\section{References}

1. Fletcher AG Jr, Gimbel NS, Riegel C. Parenteral nutrition with human serum albumin as the source of protein in the early post-operative period. Surg Gynecol Obstet 1950;90:151-154. [PubMed: 15401962]

2. Turner FP. Hyperalimentation in the management of pyloric obstruction with comments on certain theoretical relationships between protein deficiency and peptic ulcer. Gastroenterology 1955;29:10611068. [PubMed: 13270831]

3. Wretlind A. The possibilities of providing adequate parenteral nutrition. Nord Med 1955;53:10131019. [PubMed: 13244876]

4. McKibbin JM, Ferry RM, Stare FJ. Parenteral Nutrition. Ii the Utilization of Emulsified Fat Given Intravenously. J Clin Invest 1946;25:679-686. [PubMed: 16695359]

5. Watkin DM. Fecal Excretion of Lipids Before, during and After Hyperalimentation with Fat Administered Intravenously. Am J Clin Nutr 1965;16:213-223. [PubMed: 14262116]

6. Watkin DM, Steinfeld JL. Nutrient and Energy Metabolism in Patients with and without Cancer during Hyperalimentation with Fat Administered Intravenously. Am J Clin Nutr 1965;16:182-212. [PubMed: 14262115]

7. Dudrick SJ. Intravenous hyperalimentation. Surgery 1970;68:726-727. [PubMed: 4990657]

8. Dudrick SJ, Allen TR. Long-term intravenous hyperalimentation. Del Med J 1971;43:149-154. [PubMed: 4998601]

9. Dudrick SJ, Wilmore DW, Vars HM, et al. Long-term total parenteral nutrition with growth, development, and positive nitrogen balance. Surgery 1968;64:134-142. [PubMed: 4968812]

10. Kudsk KA, Croce MA, Fabian TC, et al. Enteral versus parenteral feeding. Effects on septic morbidity after blunt and penetrating abdominal trauma. Ann Surg 1992;215:503-11. [PubMed: 1616387] discussion 511-3

11. Moore EE, Jones TN. Benefits of immediate jejunostomy feeding after major abdominal trauma--a prospective, randomized study. J Trauma 1986;26:874-881. [PubMed: 3095557]

12. Moore FA, Moore EE, Jones TN, et al. TEN versus TPN following major abdominal trauma--reduced septic morbidity. J Trauma 1989;29:916-22. [PubMed: 2501509]discussion 922-3

13. Moore FA, Feliciano DV, Andrassy RJ, et al. Early enteral feeding, compared with parenteral, reduces postoperative septic complications. The results of a meta-analysis. Ann Surg 1992;216:172-183. [PubMed: 1386982]

14. McGhee JR, Mestecky J, Dertzbaugh MT, et al. The mucosal immune system: from fundamental concepts to vaccine development. Vaccine 1992;10:75-88. [PubMed: 1539467] 
15. Kudsk KA. Current aspects of mucosal immunology and its influence by nutrition. Am J Surg 2002;183:390-398. [PubMed: 11975926]

16. Kang W, Kudsk KA. Is there evidence that the gut contributes to mucosal immunity in humans? JPEN J Parenter Enteral Nutr 2007;31:246-258. [PubMed: 17463152]

17. Tomasi TB Jr, Tan EM, Solomon A, et al. Characteristics of an Immune System Common to Certain External Secretions. J Exp Med 1965;121:101-124. [PubMed: 14253478]

18. Mestecky J, McGhee JR, Arnold RR, et al. Selective induction of an immune response in human external secretions by ingestion of bacterial antigen. J Clin Invest 1978;61:731-737. [PubMed: 641151]

19. Czerkinsky C, Prince SJ, Michalek SM, et al. IgA antibody-producing cells in peripheral blood after antigen ingestion: evidence for a common mucosal immune system in humans. Proc Natl Acad Sci U S A 1987;84:2449-2453. [PubMed: 3470804]

20. Brandtzaeg P, Pabst R. Let's go mucosal: communication on slippery ground. Trends Immunol 2004;25:570-577. [PubMed: 15489184]

21. Craig SW, Cebra JJ. Peyer's patches: an enriched source of precursors for IgA-producing immunocytes in the rabbit. J Exp Med 1971;134:188-200. [PubMed: 4934147]

22. Husband AJ, Gowans JL. The origin and antigen-dependent distribution of IgA-containing cells in the intestine. J Exp Med 1978;148:1146-1160. [PubMed: 722238]

23. Brandtzaeg P, Johansen FE. Mucosal B cells: phenotypic characteristics, transcriptional regulation, and homing properties. Immunol Rev 2005;206:32-63. [PubMed: 16048541]

24. Jang MH, Kweon MN, Iwatani K, et al. Intestinal villous M cells: an antigen entry site in the mucosal epithelium. Proc Natl Acad Sci U S A 2004;101:6110-6115. [PubMed: 15071180]

25. Pachynski RK, Wu SW, Gunn MD, et al. Secondary lymphoid-tissue chemokine (SLC) stimulates integrin alpha 4 beta 7-mediated adhesion of lymphocytes to mucosal addressin cell adhesion molecule-1 (MAdCAM-1) under flow. J Immunol 1998;161:952-956. [PubMed: 9670974]

26. Brandtzaeg P, Berstad AE, Farstad IN, et al. Mucosal immunity--a major adaptive defence mechanism. Behring Inst Mitt 1997;(98):1-23. [PubMed: 9382729]

27. Lebman, DA.; Coffman, RL. Cytokines in the mucosal immune system. In: Ogra, PL.; Lamm, ME.; McGhee, JR., editors. Handbook of mucosal immunology. San Diego: Academic; 1994. p. 243-249.

28. Brandtzaeg P. Presence of J chain in human immunocytes containing various immunoglobulin classes. Nature 1974;252:418-420. [PubMed: 4215033]

29. Brandtzaeg P, Prydz H. Direct evidence for an integrated function of J chain and secretory component in epithelial transport of immunoglobulins. Nature 1984;311:71-73. [PubMed: 6433206]

30. Kaetzel, CS.; Mostov, K. Immunoglobulin transport and the polymeric immunoglobulin receptor. In: Mestecky, J.; Bienenstock, J.; Lamm, M., et al., editors. Mucosal Immunology. San Diego: Academic Press, Inc; 2005. p. 211-250.

31. Niederman MS, Merrill WW, Polomski LM, et al. Influence of sputum IgA and elastase on tracheal cell bacterial adherence. Am Rev Respir Dis 1986;133:255-260. [PubMed: 3080931]

32. Kress HG, Scheidewig C, Schmidt H, et al. Reduced incidence of postoperative infection after intravenous administration of an immunoglobulin A-and immunoglobulin M-enriched preparation in anergic patients undergoing cardiac surgery. Crit Care Med 1999;27:1281-1287. [PubMed: 10446821]

33. Lycke N, Eriksen L, Holmgren J. Protection against cholera toxin after oral immunization is thymusdependent and associated with intestinal production of neutralizing IgA antitoxin. Scand J Immunol 1987;25:413-419. [PubMed: 3576135]

34. Fagarasan S, Honjo T. Intestinal IgA synthesis: regulation of front-line body defences. Nat Rev Immunol 2003;3:63-72. [PubMed: 12511876]

35. Macpherson AJ, Gatto D, Sainsbury E, et al. A primitive T cell-independent mechanism of intestinal mucosal IgA responses to commensal bacteria. Science 2000;288:2222-2226. [PubMed: 10864873]

36. Kroese FG, Butcher EC, Stall AM, et al. Many of the IgA producing plasma cells in murine gut are derived from self-replenishing precursors in the peritoneal cavity. Int Immunol 1989;1:75-84. [PubMed: 2487677] 
37. Fujimura Y, Haruma K, Owen RL. Bombesin prevents the atrophy of Peyer's patches and the dysfunction of $\mathrm{M}$ cells in rabbits receiving long-term parenteral nutrition. JPEN J Parenter Enteral Nutr 2007;31:75-85. [PubMed: 17308247]

38. Li J, Kudsk KA, Gocinski B, et al. Effects of parenteral and enteral nutrition on gut-associated lymphoid tissue. J Trauma 1995;39:44-51. [PubMed: 7636909]discussion 51-2

39. King BK, Li J, Kudsk KA. A temporal study of TPN-induced changes in gut-associated lymphoid tissue and mucosal immunity. Arch Surg 1997;132:1303-1309. [PubMed: 9403534]

40. Brandtzaeg P, Farstad IN, Johansen FE, et al. The B-cell system of human mucosae and exocrine glands. Immunol Rev 1999;171:45-87. [PubMed: 10582165]

41. Bargatze RF, Jutila MA, Butcher EC. Distinct roles of L-selectin and integrins alpha 4 beta 7 and LFA-1 in lymphocyte homing to Peyer's patch-HEV in situ: the multistep model confirmed and refined. Immunity 1995;3:99-108. [PubMed: 7542550]

42. Berlin C, Berg EL, Briskin MJ, et al. Alpha 4 beta 7 integrin mediates lymphocyte binding to the mucosal vascular addressin MAdCAM-1. Cell 1993;74:185-195. [PubMed: 7687523]

43. Zarzaur BL, Fukatsu K, Johnson CJ, et al. A temporal study in diet induced changes in Peyer patch MAdCAM-1 expression. Surg Forum 2001;52:194-196.

44. Gomez FE, Lan J, Kang W, et al. Parenteral nutrition and fasting reduces mucosal addressin cellular adhesion molecule-1 (MAdCAM-1) mRNA in Peyer's patches of mice. JPEN J Parenter Enteral Nutr 2007;31:47-52. [PubMed: 17202440]

45. Ikeda S, Kudsk KA, Fukatsu K, et al. Enteral feeding preserves mucosal immunity despite in vivo MAdCAM-1 blockade of lymphocyte homing. Ann Surg 2003;237:677-85. [PubMed: 12724634] discussion 685

46. Kang W, Gomez FE, Lan J, et al. Parenteral nutrition impairs gut-associated lymphoid tissue and mucosal immunity by reducing lymphotoxin Beta receptor expression. Ann Surg 2006;244:392-399. [PubMed: 16926565]

47. Browning JL, Allaire N, Ngam-Ek A, et al. Lymphotoxin-beta receptor signaling is required for the homeostatic control of HEV differentiation and function. Immunity 2005;23:539-550. [PubMed: 16286021]

48. Dohi T, Rennert PD, Fujihashi K, et al. Elimination of colonic patches with lymphotoxin beta receptorIg prevents Th2 cell-type colitis. J Immunol 2001;167:2781-2790. [PubMed: 11509623]

49. Dejardin E, Droin NM, Delhase M, et al. The lymphotoxin-beta receptor induces different patterns of gene expression via two NF-kappaB pathways. Immunity 2002;17:525-535. [PubMed: 12387745]

50. Kang W, Kudsk KA, Sano Y, et al. Effects of lymphotoxin beta receptor blockade on intestinal mucosal immunity. JPEN J Parenter Enteral Nutr 2007;31:358-64. [PubMed: 17712143]discussion $364-5$

51. Janu P, Li J, Renegar KB, et al. Recovery of gut-associated lymphoid tissue and upper respiratory tract immunity after parenteral nutrition. Ann Surg 1997;225:707-15. [PubMed: 9230811]discussion $715-7$

52. Parrott DM. The gut as a lymphoid organ. Clin Gastroenterol 1976;5:211-228. [PubMed: 798640]

53. Alverdy JC, Aoys E, Moss GS. Total parenteral nutrition promotes bacterial translocation from the gut. Surgery 1988;104:185-190. [PubMed: 3135625]

54. Alverdy JC, Aoys E, Moss GS. Effect of commercially available chemically defined liquid diets on the intestinal microflora and bacterial translocation from the gut. JPEN J Parenter Enteral Nutr 1990;14:1-6. [PubMed: 2325237]

55. Spaeth G, Gottwald T, Specian RD, et al. Secretory immunoglobulin A, intestinal mucin, and mucosal permeability in nutritionally induced bacterial translocation in rats. Ann Surg 1994;220:798-808. [PubMed: 7986148]

56. Deitch EA, Ma WJ, Ma L, et al. Protein malnutrition predisposes to inflammatory-induced gut-origin septic states. Ann Surg 1990;211:560-7. [PubMed: 2111125]discussion 567-8

57. Nayci A, Atis S, Ersoz G, et al. Gut decontamination prevents bronchoscopy-induced bacterial translocation. An experimental study in rats. Respiration 2004;71:66-71. [PubMed: 14872113]

58. Wu GH, Wang H, Zhang YW, et al. Glutamine supplemented parenteral nutrition prevents intestinal ischemia- reperfusion injury in rats. World J Gastroenterol 2004;10:2592-2594. [PubMed: 15300914] 
59. MacFie J, O'Boyle C, Mitchell CJ, et al. Gut origin of sepsis: a prospective study investigating associations between bacterial translocation, gastric microflora, and septic morbidity. Gut 1999;45:223-228. [PubMed: 10403734]

60. O'Boyle CJ, MacFie J, Mitchell CJ, et al. Microbiology of bacterial translocation in humans. Gut 1998;42:29-35. [PubMed: 9505882]

61. Sedman PC, MacFie J, Palmer MD, et al. Preoperative total parenteral nutrition is not associated with mucosal atrophy or bacterial translocation in humans. Br J Surg 1995;82:1663-1667. [PubMed: 8548235]

62. Macpherson AJ, McCoy KD, Johansen FE, et al. The immune geography of IgA induction and function. Muc Immunol 2008;1:11-22.

63. Fukatsu K, Lundberg AH, Hanna MK, et al. Route of nutrition influences intercellular adhesion molecule-1 expression and neutrophil accumulation in intestine. Arch Surg 1999;134:1055-1060. [PubMed: 10522845]

64. Fukatsu K, Lundberg AH, Hanna MK, et al. Increased expression of intestinal P-selectin and pulmonary E-selectin during intravenous total parenteral nutrition. Arch Surg 2000;135:1177-1182. [PubMed: 11030875]

65. Fukatsu K, Kudsk KA, Zarzaur BL, et al. Increased ICAM-1 and beta2 integrin expression in parenterally fed mice after a gut ischemic insult. Shock 2002;18:119-124. [PubMed: 12166773]

66. Fukatsu K, Zarzaur BL, Johnson CD, et al. Enteral nutrition prevents remote organ injury and death after a gut ischemic insult. Ann Surg 2001;233:660-668. [PubMed: 11323505]

67. Wildhaber BE, Yang H, Spencer AU, et al. Lack of enteral nutrition--effects on the intestinal immune system. J Surg Res 2005;123:8-16. [PubMed: 15652945]

68. Lin MT, Saito H, Fukushima R, et al. Preoperative total parenteral nutrition influences postoperative systemic cytokine responses after colorectal surgery. Nutrition 1997;13:8-12. [PubMed: 9058440]

69. Takagi K, Yamamori H, Toyoda Y, et al. Modulating effects of the feeding route on stress response and endotoxin translocation in severely stressed patients receiving thoracic esophagectomy. Nutrition 2000;16:355-360. [PubMed: 10793304]

70. Fong YM, Marano MA, Barber A, et al. Total parenteral nutrition and bowel rest modify the metabolic response to endotoxin in humans. Ann Surg 1989;210:449-56. [PubMed: 2508583]discussion 4567

71. Brandtzaeg P, Kiyono H, Pabst R, et al. Terminology: nomenclature of mucosa-associated lymphoid tissue. Muc Immunol 2008;1:31-37.

72. Sonoda E, Hitoshi Y, Yamaguchi N, et al. Differential regulation of IgA production by TGF-beta and IL-5: TGF-beta induces surface IgA-positive cells bearing IL-5 receptor, whereas IL-5 promotes their survival and maturation into IgA-secreting cells. Cell Immunol 1992;140:158-172. [PubMed: 1739984]

73. Wu Y, Kudsk KA, DeWitt RC, et al. Route and type of nutrition influence IgA-mediating intestinal cytokines. Ann Surg 1999;229:662-7. [PubMed: 10235524]discussion 667-8

74. Fukatsu K, Kudsk KA, Zarzaur BL, et al. TPN decreases IL-4 and IL-10 mRNA expression in lipopolysaccharide stimulated intestinal lamina propria cells but glutamine supplementation preserves the expression. Shock 2001;15:318-322. [PubMed: 11303733]

75. Kaetzel, CS.; Bruno, MEC. Epithelial Transport of IgA by the Ploymeric Immunoglobulin Receptor. In: Kaetzel, CS., editor. Mucosal Immune Defense: Immunoglobulin A. New York: Springer; 2007. p. 43-89.

76. Hirunsatit R, Kongruttanachok N, Shotelersuk K, et al. Polymeric immunoglobulin receptor polymorphisms and risk of nasopharyngeal cancer. BMC Genet 2003;4:3. [PubMed: 12546713]

77. Obara W, Iida A, Suzuki Y, et al. Association of single-nucleotide polymorphisms in the polymeric immunoglobulin receptor gene with immunoglobulin A nephropathy (IgAN) in Japanese patients. J Hum Genet 2003;48:293-299. [PubMed: 12740691]

78. Johansen, FE.; Braathen, R.; Manthe, E., et al. Regulation of the Mucosal IgA System. In: Kaetzel, CS., editor. Mucosal Immune Defense: Immunoglobulin A. New York: Springer; 2007. p. 111-143.

79. Lycke N, Erlandsson L, Ekman L, et al. Lack of J chain inhibits the transport of gut IgA and abrogates the development of intestinal antitoxic protection. J Immunol 1999;163:913-919. [PubMed: 10395687] 
80. Hendrickson BA, Conner DA, Ladd DJ, et al. Altered hepatic transport of immunoglobulin A in mice lacking the J chain. J Exp Med 1995;182:1905-1911. [PubMed: 7500036]

81. Mazanec MB, Nedrud JG, Kaetzel CS, et al. A three-tiered view of the role of IgA in mucosal defense. Immunol Today 1993;14:430-435. [PubMed: 8216720]

82. de Oliveira IR, de Araujo AN, Bao SN, et al. Binding of lactoferrin and free secretory component to enterotoxigenic Escherichia coli. FEMS Microbiol Lett 2001;203:29-33. [PubMed: 11557136]

83. Boren T, Falk P, Roth KA, et al. Attachment of Helicobacter pylori to human gastric epithelium mediated by blood group antigens. Science 1993;262:1892-1895. [PubMed: 8018146]

84. Dallas SD, Rolfe RD. Binding of Clostridium difficile toxin A to human milk secretory component. J Med Microbiol 1998;47:879-888. [PubMed: 9788811]

85. Royle L, Roos A, Harvey DJ, et al. Secretory IgA N- and O-glycans provide a link between the innate and adaptive immune systems. J Biol Chem 2003;278:20140-20153. [PubMed: 12637583]

86. Kaetzel CS. Polymeric Ig receptor: defender of the fort or Trojan horse? Curr Biol 2001;11:R35-8. [PubMed: 11166195]

87. Sano Y, Gomez FE, Kang W, et al. Intestinal polymeric immunoglobulin receptor (pIgR) is affected by type and route of nutrition. JPEN 2007;31:S15-S15.

88. Chapin SJ, Enrich C, Aroeti B, et al. Calmodulin binds to the basolateral targeting signal of the polymeric immunoglobulin receptor. J Biol Chem 1996;271:1336-1342. [PubMed: 8576121]

89. Okamoto CT, Song W, Bomsel M, et al. Rapid internalization of the polymeric immunoglobulin receptor requires phosphorylated serine 726. J Biol Chem 1994;269:15676-15682. [PubMed: 8195218]

90. Johnson CD, Kudsk KA, Fukatsu K, et al. Route of nutrition influences generation of antibodyforming cells and initial defense to an active viral infection in the upper respiratory tract. Ann Surg 2003;237:565-573. [PubMed: 12677154]

91. Renegar KB, Johnson CD, Dewitt RC, et al. Impairment of mucosal immunity by total parenteral nutrition: requirement for IgA in murine nasotracheal anti-influenza immunity. J Immunol 2001;166:819-825. [PubMed: 11145655]

92. King BK, Kudsk KA, Li J, et al. Route and type of nutrition influence mucosal immunity to bacterial pneumonia. Ann Surg 1999;229:272-278. [PubMed: 10024110]

93. Kudsk KA, Hermsen JL, Genton L, et al. Injury stimulates an innate respiratory immunoglobulin a immune response in humans. J Trauma 2008;64:316-23. [PubMed: 18301193]discussion 323-5

94. Pine R. Convergence of TNFalpha and IFNgamma signalling pathways through synergistic induction of IRF-1/ISGF-2 is mediated by a composite GAS/kappaB promoter element. Nucleic Acids Res 1997;25:4346-4354. [PubMed: 9336467]

95. Schjerven H, Tran TN, Brandtzaeg P, et al. De novo synthesized RelB mediates TNF-induced upregulation of the human polymeric Ig receptor. J Immunol 2004;173:1849-1857. [PubMed: 15265917]

96. Bruno ME, Kaetzel CS. Long-term exposure of the HT-29 human intestinal epithelial cell line to TNF causes sustained up-regulation of the polymeric Ig receptor and proinflammatory genes through transcriptional and posttranscriptional mechanisms. J Immunol 2005;174:7278-7284. [PubMed: 15905574]

97. Schmidt LD, Xie Y, Lyte M, et al. Autonomic neurotransmitters modulate immunoglobulin A secretion in porcine colonic mucosa. J Neuroimmunol 2007;185:20-28. [PubMed: 17320195]

98. Li J, Kudsk KA, Janu P, et al. Effect of glutamine-enriched total parenteral nutrition on small intestinal gut-associated lymphoid tissue and upper respiratory tract immunity. Surgery 1997;121:542-549. [PubMed: 9142153]

99. DeWitt RC, Wu Y, Renegar KB, et al. Glutamine-enriched total parenteral nutrition preserves respiratory immunity and improves survival to a Pseudomonas Pneumonia. J Surg Res 1999;84:1318. [PubMed: 10334882]

100. Erspamer V, Erpamer GF, Inselvini M. Some pharmacological actions of alytesin and bombesin. J Pharm Pharmacol 1970;22:875-876. [PubMed: 4395815]

101. McDonald TJ, Nilsson G, Vagne M, et al. A gastrin releasing peptide from the porcine nonantral gastric tissue. Gut 1978;19:767-774. [PubMed: 361511] 
102. Delle Fave G, Kohn A, De Magistris L, et al. Effects of bombesin on gastrin and gastric acid secretion in patients with duodenal ulcer. Gut 1983;24:231-235. [PubMed: 6826108]

103. Lieverse RJ, Jansen JB, van de Zwan A, et al. Bombesin reduces food intake in lean man by a cholecystokinin-independent mechanism. J Clin Endocrinol Metab 1993;76:1495-1498. [PubMed: 8501156]

104. Lieverse RJ, Masclee AA, Jansen JB, et al. Obese women are less sensitive for the satiety effects of bombesin than lean women. Eur J Clin Nutr 1998;52:207-212. [PubMed: 9537307]

105. Vulchanova L, Casey MA, Crabb GW, et al. Anatomical evidence for enteric neuroimmune interactions in Peyer's patches. J Neuroimmunol 2007;185:64-74. [PubMed: 17363074]

106. DeWitt RC, Wu Y, Renegar KB, et al. Bombesin recovers gut-associated lymphoid tissue and preserves immunity to bacterial pneumonia in mice receiving total parenteral nutrition. Ann Surg 2000;231:1-8. [PubMed: 10636095]

107. Zarzaur BL, Wu Y, Fukatsu K, et al. The neuropeptide bombesin improves IgA-mediated mucosal immunity with preservation of gut interleukin-4 in total parenteral nutrition-fed mice. Surgery 2002;131:59-65. [PubMed: 11812964]

108. Zarzaur BL, Ikeda S, Johnson CD, et al. Mucosal immunity preservation with bombesin or glutamine is not dependent on mucosal addressin cell adhesion molecule-1 expression. JPEN J Parenter Enteral Nutr 2002;26:265-70. [PubMed: 12216704]discussion 270

109. Annane D, Clair B, Mathieu B, et al. Immunoglobulin A levels in bronchial samples during mechanical ventilation and onset of nosocomial pneumonia in critically ill patients. Am J Respir Crit Care Med 1996;153:1585-1590. [PubMed: 8630606]

110. Perkkio M, Savilahti E. Time of appearance of immunoglobulin-containing cells in the mucosa of the neonatal intestine. Pediatr Res 1980;14:953-955. [PubMed: 7191555]

111. Knox WF. Restricted feeding and human intestinal plasma cell development. Arch Dis Child 1986;61:744-749. [PubMed: 3090947]

112. Machado CS, Rodrigues MA, Maffei HV. Assessment of gut intraepithelial ymphocytes during late gestation and the neonatal period. Biol Neonate 1994;66:324-329. [PubMed: 7727614]

113. Okamoto K, Fukatsu K, Ueno C, et al. T lymphocyte numbers in human gut associated lymphoid tissue are reduced without enteral nutrition. JPEN J Parenter Enteral Nutr 2005;29:56-58. [PubMed: 15715275]

114. Wijesinha SS, Steer HW. Studies of the immunoglobulin-producing cells of the human intestine: the defunctioned bowel. Gut 1982;23:211-214. [PubMed: 7040176]

115. Buchman AL, Mestecky J, Moukarzel A, et al. Intestinal immune function is unaffected by parenteral nutrition in man. J Am Coll Nutr 1995;14:656-661. [PubMed: 8598428]

Langenbecks Arch Surg. Author manuscript; available in PMC 2010 January 1. 


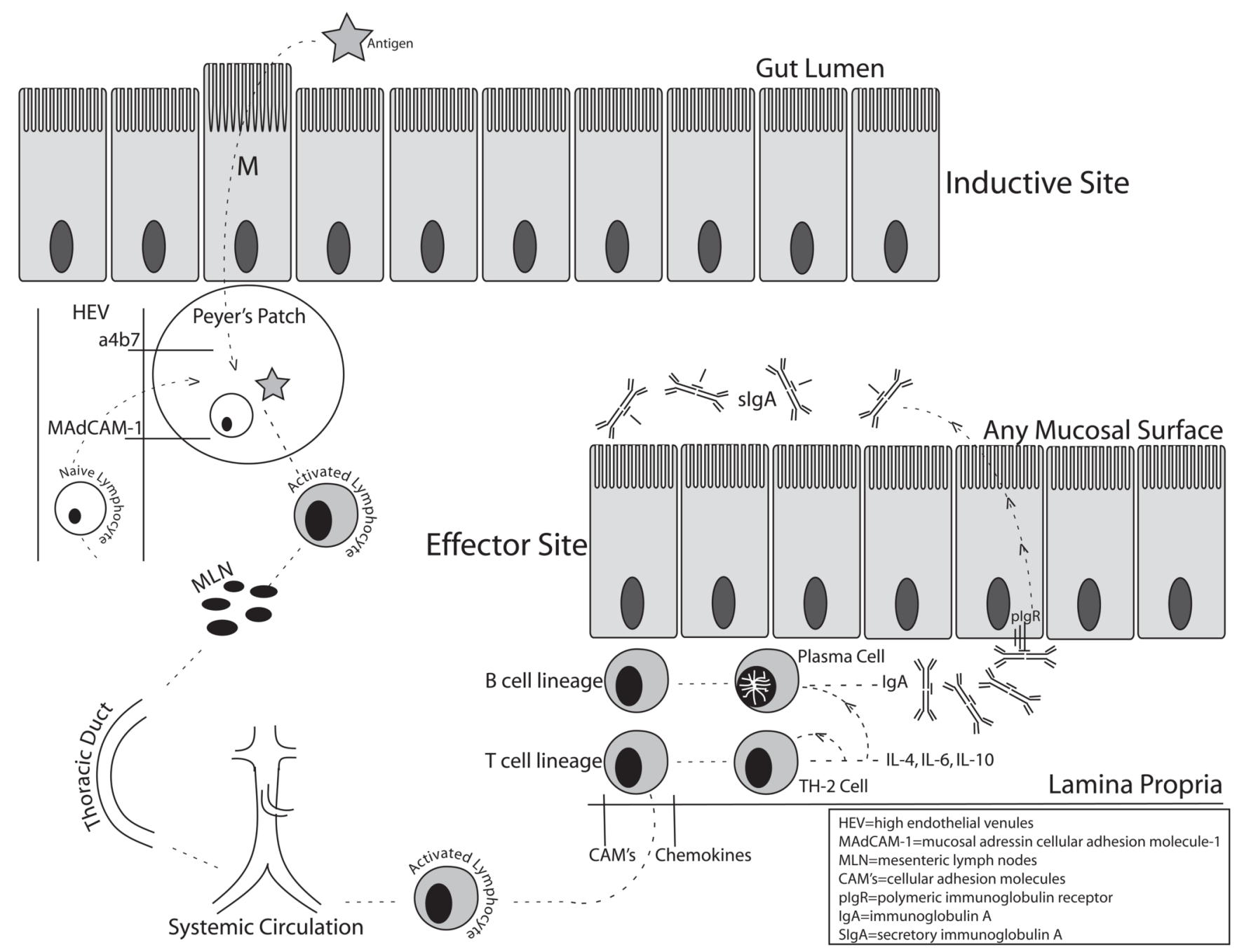

Figure 1.

Schematic representation of a typical mucosal immune response. The process begins with antigen sampling and recognition at inductive sites and ends with the generation of antigen specific secretory immunoglobulin A at effector sites which is actively transported to the mucosal surface. 


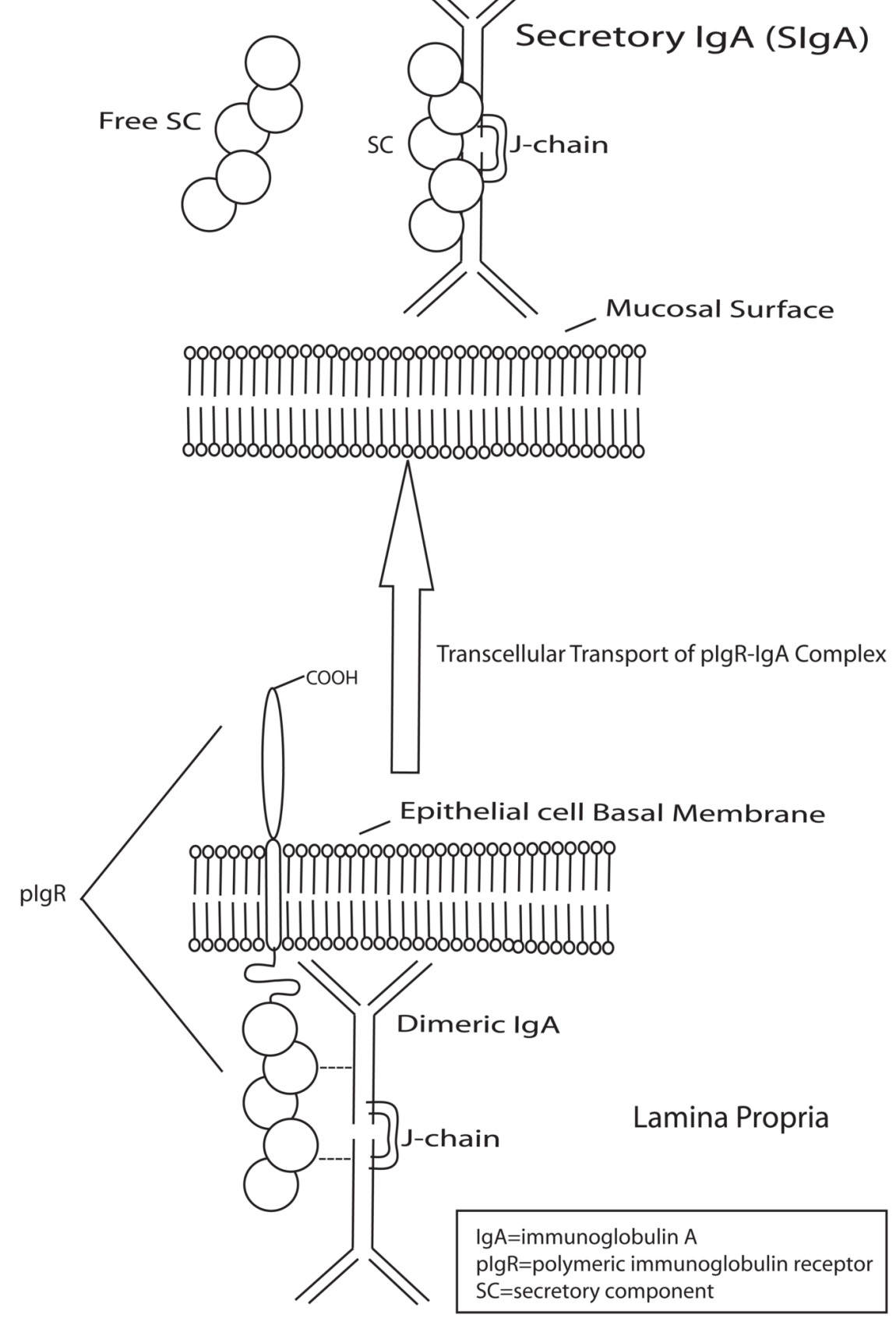

Figure 2.

The relationship between $\mathrm{pIgR}$ and dimeric $\operatorname{IgA}$. Dimeric $\operatorname{Ig} \mathrm{A}$ generated in the lamina propria is bound, and transported across the epithelium, by $\mathrm{pIgR}$. As the $\mathrm{pIgR} / \operatorname{IgA}$ complex is released into the lumen, a portion of the $\mathrm{pIgR}$ protein remains with the $\operatorname{IgA}$ to form secretory $\operatorname{IgA}$. Free secretory component is generated if $\mathrm{pIgR}$ is transported without first binding $\operatorname{Ig} \mathrm{A}$. 
Response of Peyer's Patch MAdCAM-1 and Lymphocyte Levels to Parenteral Nutrition

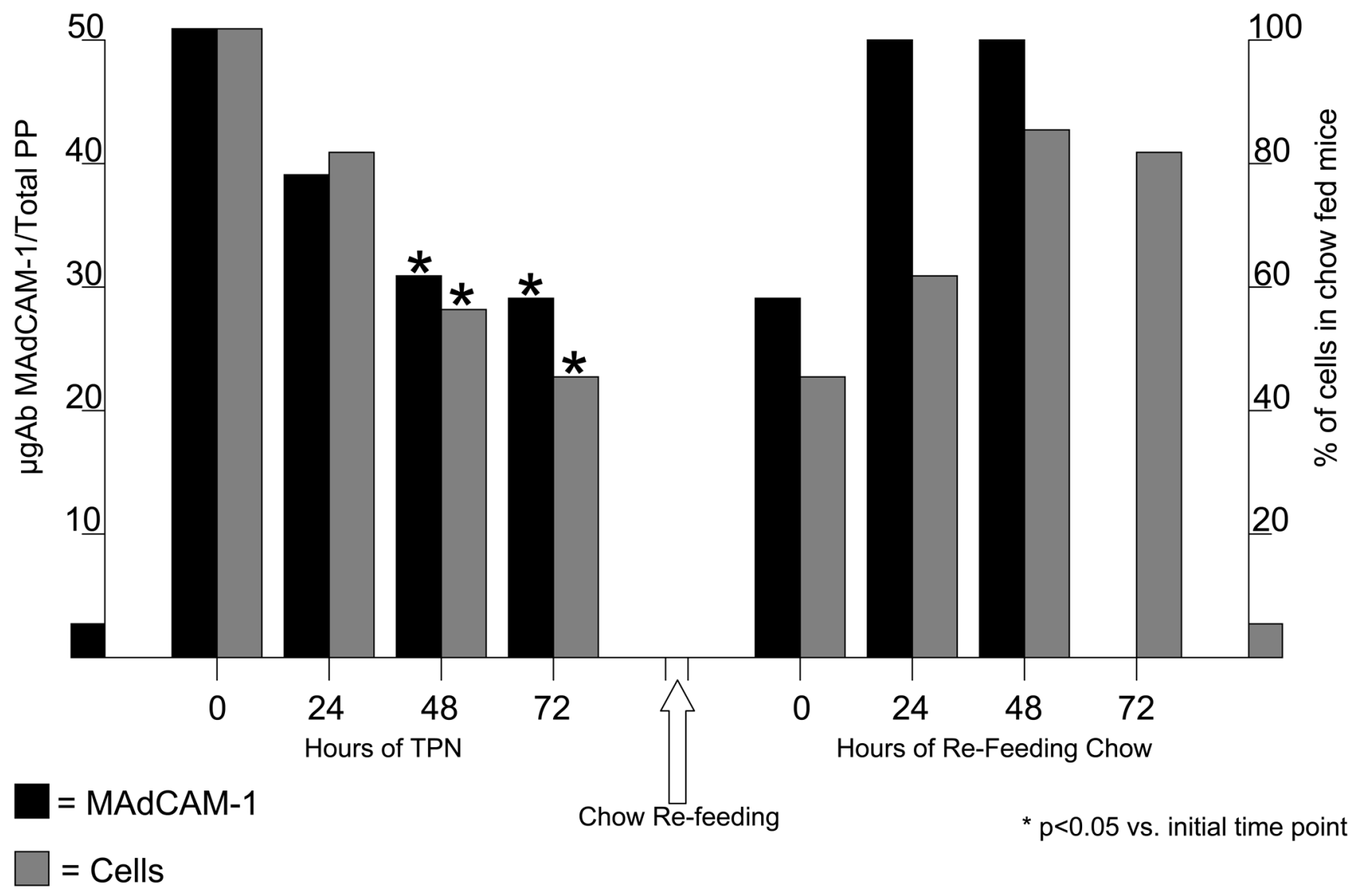

Figure 3.

The level of MAdCAM-1 and the numbers of lymphocytes in the Peyer's patches decline in parallel fashion with parenteral feeding / decreased enteral stimulation. These changes are reversed with refeeding of an enteral diet. 
Intestinal plgR Expression

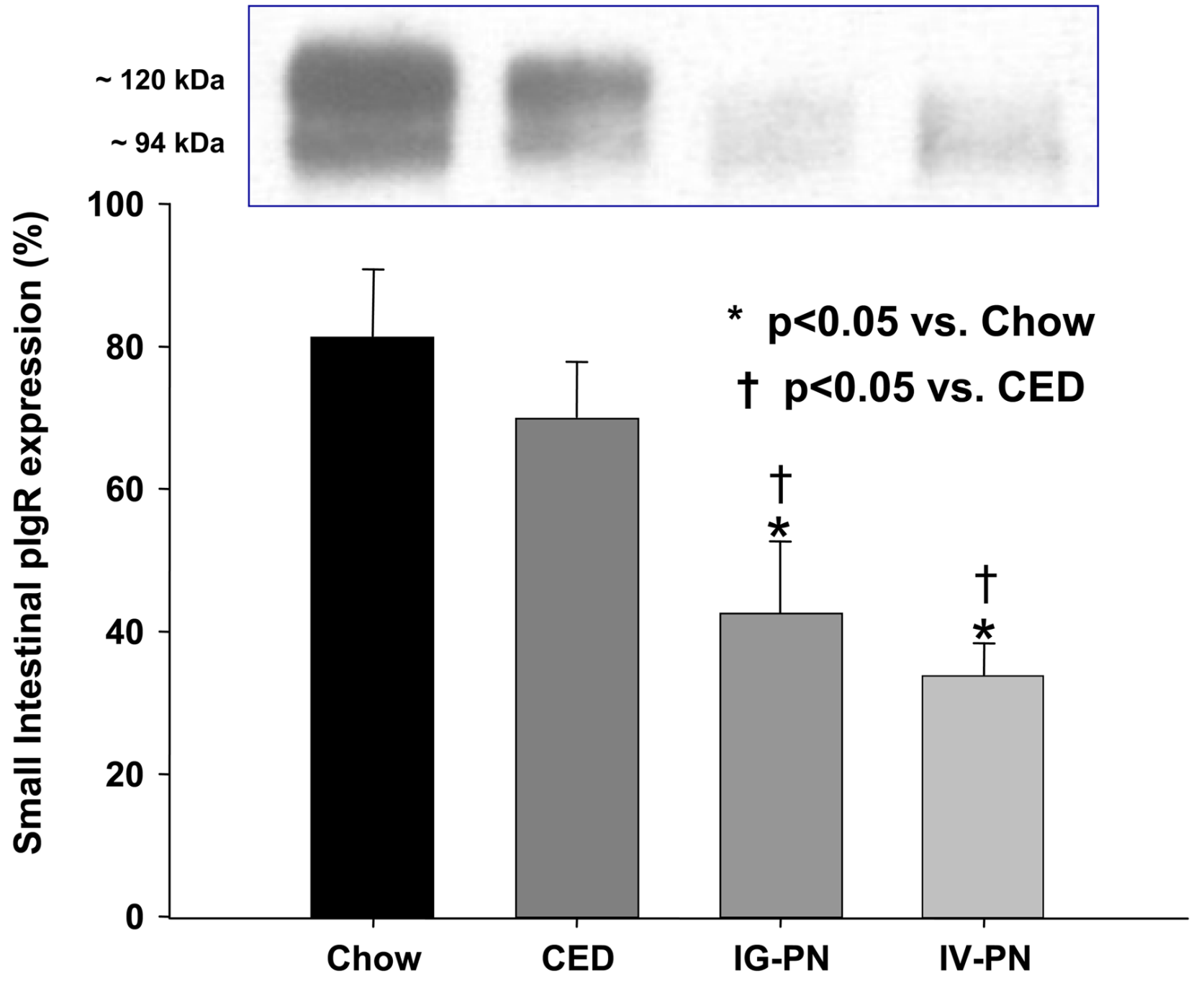

Figure 4.

The level of pIgR in the small intestine declines in a stepwise fashion according to type and route of nutrition. $\mathrm{CED}=$ complex enteral diet (ie: tube feeds), IG-PN= intragastric parenteral nutrition (ie: elemental diet), IV-PN= intravenous parenteral nutrition. 
Effect of Parenteral Feeding on Intestinal and Respiratory Tract IgA Levels

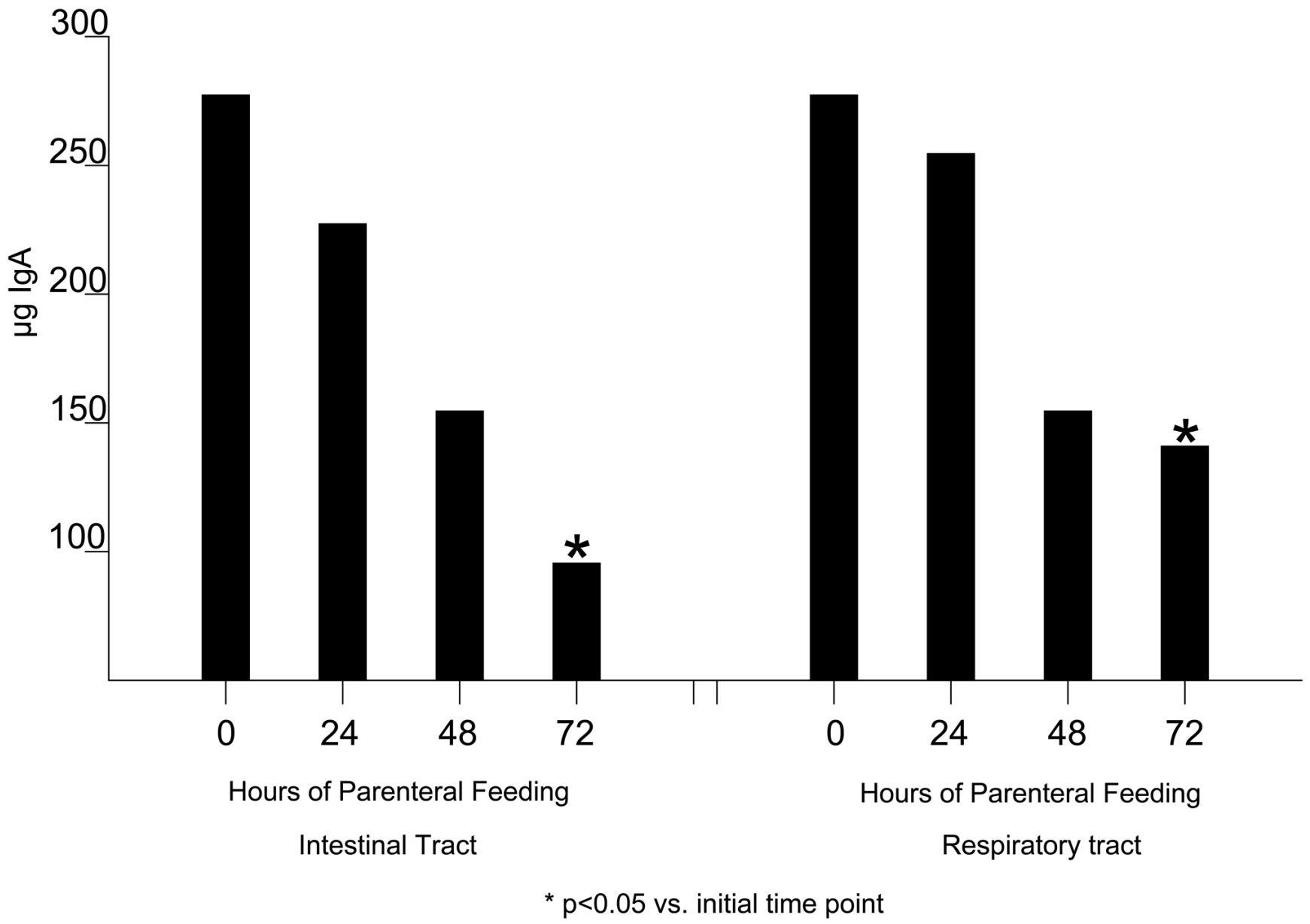

Figure 5.

IgA levels in the intestinal and respiratory tracts decline with parenteral feeding / decreased enteral stimulation. 

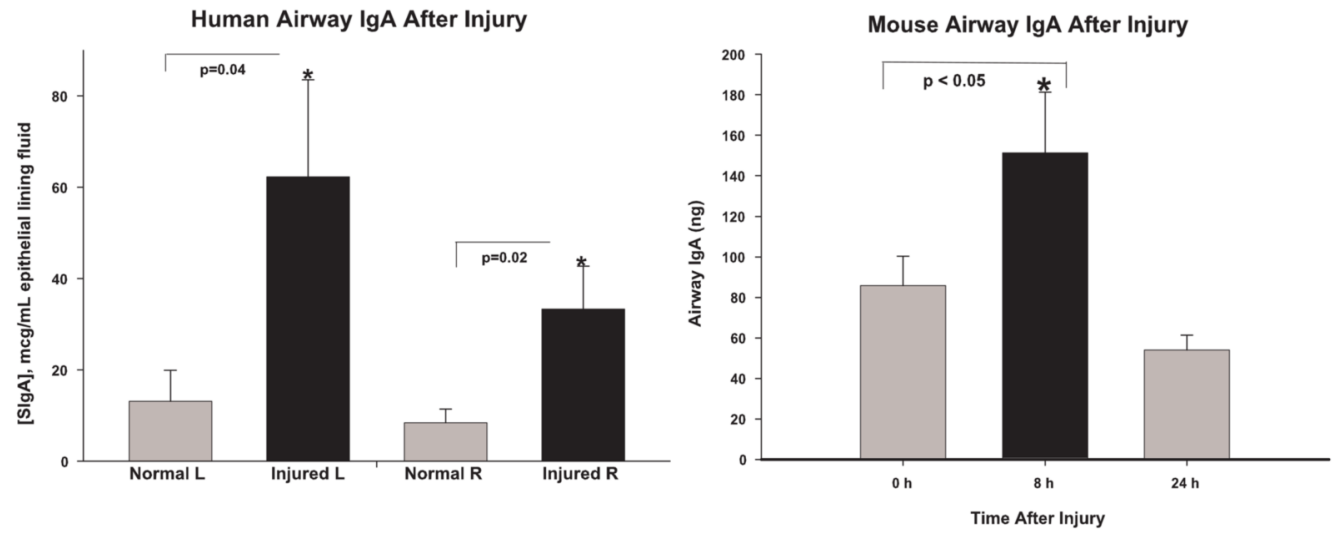

Figure 6.

Injury causes acute increases in respiratory tract $\operatorname{IgA}$ levels in both humans and mice. 
Mouse Airway IgA Response to Injury with PN and TNF-a Blockade Pre-Treatments

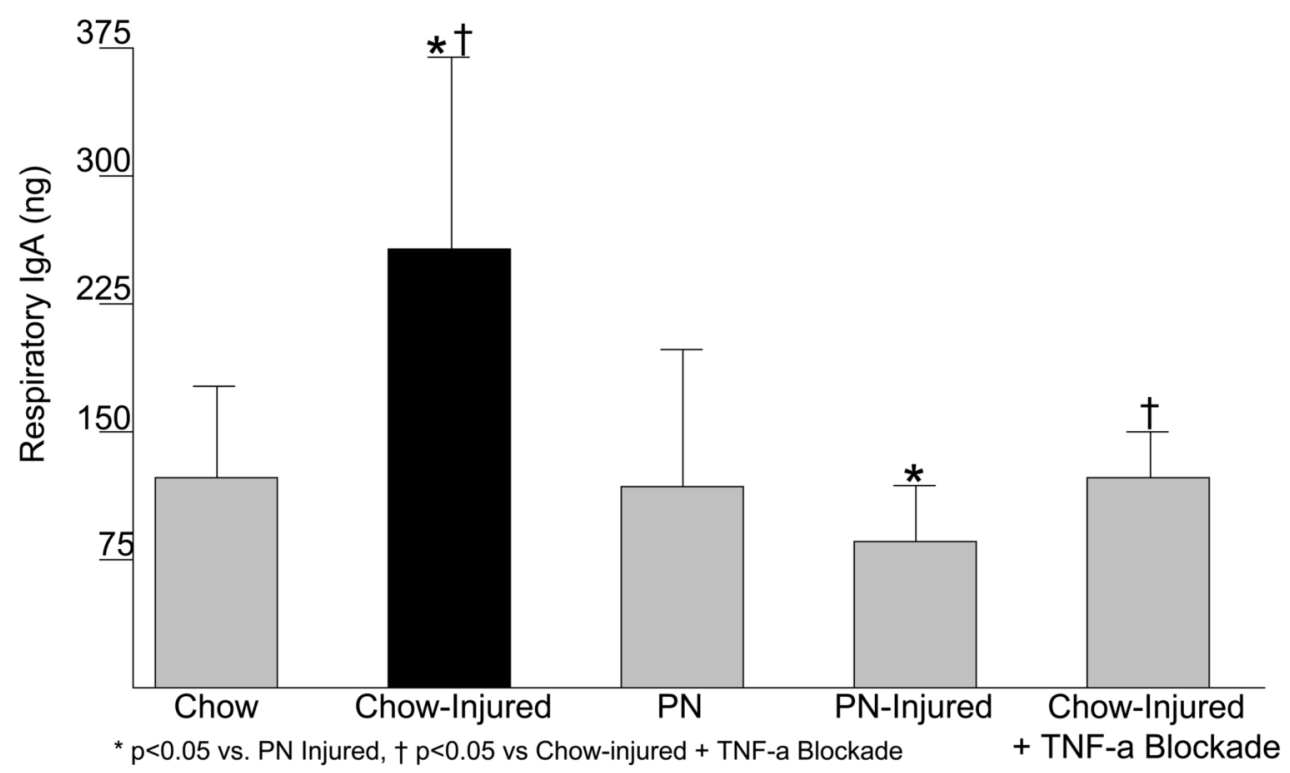

Figure 7.

Injury induced increases in respiratory tract IgA are abrogated by pre-injury parenteral feeding / decreased enteral stimulation or pre-injury blockade of tumor necrosis factor alpha function with a monoclonal antibody. 
Table 1

Effect of PN/DES on Intestinal Cytokines, Adhesion Molecules and Neutrophils

\begin{tabular}{lc}
\hline IL-4 & $\downarrow$ \\
IL-5 & No $\Delta$ \\
IL-6 & No $\Delta$ \\
IL-10 & $\downarrow$ \\
IFN- $\gamma$ & No $\Delta$ \\
ICAM-1 & $\uparrow$ \\
P-selectin (gut) & $\uparrow$ \\
E-selectin (lung) & $\uparrow$ \\
Myeloperoxidase & $\uparrow$ \\
\hline
\end{tabular}

(All changes are statistically significant with $\mathrm{p}<0.05 \mathrm{PN} / \mathrm{DES}$ vs. chow groups, $\Delta=$ change) 